\title{
Penerapan Grammarly Tool Untuk Meningkatkan Keterampilan Menulis Teks Analisis Ekspositoris Siswa
}

\author{
Endang Sulistyowati \\ SMA Negeri 1 Jalaksana \\ endangsulistiyo22@gmail.com
}

\begin{abstract}
The objective of this study is to boost students" writing skill by using Grammarly tool of the eleventh grade students of SMAN 1 Jalasana in the academic year of 2019/2020. The subject of this study were students of XI MIPA 4 class, consists of 35 students. The method of this study is Classroom Action Research (CAR). This study is conducted based on a collaborative classroom action research where researchers as English teachers in Class XI MIPA 4 collaborate with English teachers who also teach at SMA Negeri 1 Jalaksana as observers and collaborators. The study is done through two cycles which each cycle consists of three meetings. Each cycle is carried out by following Kemmis \& McTaggart model that consists of planning, acting, observing, and reflecting. The technique of collecting the data used in this study were interviews, field notes, questionnaires, and tests. The writer then analyzed the data, both quantitatively and qualitatively. The writer carried out the pre-test, test in cycle 1 and cycle 2 to measure the students" writing skill, particularly in writing analytical exposition text. The result of this study showed that there was a significant improvement in students "writing skill after implementing Grammarly tool in writing class. By the end of each period, most the students obtained satisfying scores after using Grammarly tool. This can be proven from the result of the students" scores in writing test of each cycle. In the pre-test, the students" mean score was $66.43 \%$. Then, after implementing Grammarly tool, the students "mean score of post-test 1 was $72.00 \%$ and post-test 2 was 80.74\%. Considering the data above, the achievement of students "writing skill in post-test 2 has achieved the target of classroom action research. It could be seen from the result that Grammarly can give positive effect on students" writing skill.
\end{abstract}

Keywords: grammarly tool, writing sklill, analytical exposition text

\section{ABSTRAK}

Penelitian ini bertujuan untuk meningkatkan keterampilan menulis siswa melalui Grammarly checker pada siswa kelas XI MIPA 4 SMA Negeri 1 Jalaksana tahun pelajaran 2019/2020. Subjek penelitian adalah siswa kelas XI MIPA 4 berjumlah 35 siswa. Metode penelitian ini adalah penelitian tindakan kelas (PTK). Penelitian ini dilakukan berdasarkan penelitian tindakan kelas kolaboratif, dimana peneliti sebagai guru Bahasa Inggris di Kelas XI MIPA 4 berkolaborasi dengan guru Bahasa Inggris yang juga mengajar di SMA Negeri 1 Jalaksana sebagai pengamat dan kolaborator. Penelitian ini dilakukan melalui dua siklus yang setiap siklus terdiri dari tiga pertemuan. Setiap siklus dilakukan dengan mengikuti model Kemmis dan Mc Taggart yang terdiri dari perencanaa, tindakan, pengamatan, dan refleksi. Teknik pengumpulan data yang digunakan dalam penelitian ini adalah wawancara, catatan lapangan, angket, dan tes. Peneliti kemudian menganalisis data, baik secara kuantitatif maupun kualitatif. Peneliti melakukan pre-test pada siklus 1 , tes pada siklus 1 dan 2 untuk mengukur keterampilan menulis siswa terutama dalam menulis teks eksposisi analitis. Hasil penelitian ini menunjukkan bahwa ada peningkatan yang signifikan terhadap keterampilan menulis siswa setelah menerapkan alat Grammarly di kelas. Pada akhir setiap periode, sebagian besar siswa memperoleh nilai yang memuaskan seteah menggunakan alat Grammarly. Hal ini dapat dibuktikan dari hasil skor siswa dalam tes tertulis dari setiap siklus. Pada pre-test, nilai rata-rata siswa adalah 66.43. kemudian, setelah menerapkan alat Grammarly, nilai rata-rata siswa pada post-test 1 adalah 72,00 dan post-test 2 adalah 80,74. Berdasarkan data di atas, pencapaian keterampilan menulis siswa pada post-test 2 telah mencapai target penelitian tindakan kelas. Dari hasil nilai rata-rata siswa bisa dilihat bahwa Grammarly dapat memberikan efek positif terhadap keterampilan menulis siswa.

Kata kunci: grammarly tool, keterampilan menulis, teks analistik ekspositoris

Submitted May 25, 2021 | Revised Jun 25, 2021 | Accepted Jun 29, 2021 


\section{Pendahuluan}

Perkembangan teknologi modern telah meningkat pesat di kehidupan manusia. Berbagai macam teknologi telah tersebar di banyak sektor, termasuk pendidikan, khususnya dalam proses belajar mengajar. Perkembangan di dunia pendidikan ikut berubak seiring dengan perkembangan jaman dimana pola pikir pendidik berubah dari konservatif menjadi lebih modern. Belajar adalah setiap perubahan yang relatif menetap dalam tingkah laku yang terjadi sebagai suatu hasil dari latihan atau pengalaman (Purwanto, 1996). Dalam bidang pendidikan, teknologi telah berpartisipasi dalam tren baru dalam pengajaran bahasa dan evaluasi bahasa (Parra G \& Calero S, 2019). Adanya teknologi telah berubah dan memberikan cara yang menarik dan mudah dalam proses belajar mengajar. Selain itu, diperlukan alat dan media dalam pembelajaran bahasa Inggris untuk membantu siswa dalam mempelajari bahasa secara efektif.Penggunaan teknologi dapat mendukung kemampuan bahasa Inggris siswa dengan menyesuaikan proses pembelajaran mereka sendiri, misalnya melalui pembelajaran daring, online game, YouTube, video, dll. (Gilakjani, 2017).

Saat ini penggunaan teknologi sudah pasti dibutuhkan dalam pembelajaran empat keterampilan bahasa, salah satunya adalah belajar menulis. Menulis tidak hanya memainkan peran penting dalam kehidupan akademik siswa, tetapi juga memiliki dasar tujuan yang memberi siswa kesempatan untuk mengekspresikan ide, dorong interaksi, buat argumen logis dan persuasif, dan persiapkan untuk sekolah dan pekerjaan. Seperti yang dikemukakan oleh Husin \& Nurbayani (2017), tulisan tersebut adalah keterampilan paling penting yang perlu dimiliki siswa, terutama EFL pelajar di Indonesia. Siswa harus menguasai cara menyusun kalimat paragraf yang tepat dan kembangkan paragraf mereka menjadi cerita atau teks bentuk yang tepat, organisasi, tata bahasa, tanda baca, ejaan, dan sebagainya. Saat ini, sebagian besar konteks kehidupan, seperti sekolah, tempat kerja, dan Masyarakat saat ini menetapkan keterampilan menulis sebagai peraturan atau persyaratan untuk dipersiapkan. Ariyanti (2016) juga menunjukkan bahwa untuk tujuan tertentu, siswa dapat memahami literatur apa pun secara luas dalam bahasa Inggris tertulis.

Berdasarkan implementasi kurikulum 2013 saat ini di Indonesia, kemampuan bahasa siswa sangat ditekankan siswa itu harus mampu berkomunikasi baik lisan maupun tulisan dalam bahasa Inggris. Salah satu bentuk tulisan yang harus dikuasai siswa adalah menulis teks. Teks adalah penyatuan ekspresi. Itu juga dikategorikan di sana berbagai jenis: informatif, naratif, dan argumentatif (Tiryaki \& Yilmaz, 2016). Teks ini memiliki tujuan dan fungsi yang berbeda dimana siswa harus memproduksinya bentuk peneliti an formal karena persyaratan akademik. Precy (2019) menyatakan perlunya siswa sekolah menengah atas untuk mempresentasikan tulisan proses penyelidikan ilmiah, eksperimen draf, esai tentang topik terbaru atau masalah sosial, makalah kritik, dan rencana mata pencaharian.

Berdasarkan observasi peneliti selama mengajar di SMA Negeri 1 Jalaksana, masalah-masalah di atas juga bisa dipengaruhi melalui peran media dalam pengajaran menulis. Beberapa guru jarang digunakan media online untuk mendukung kelas menulis. Media dalam mengajar tetap diandalkan buku teks dan siswa tidak dilatih untuk berlatih lebih banyak menulis. Oleh karena itu, siswa kurang memahami dan tidak tertarik untuk menulis.

Dalam penelitian ini teks eksposisi analitik dipilih. Peneliti punya dua alasan untuk memilih teks eksposisi analitik sebagai instrumen. Pertama, teks ekspositori analitis sulit. Senada dengan Yusna (2017), diindikasikan sebagian besar siswa kelas sebelas mengalami kesulitan dalam memahami teks eksposisi analitis. Meskipun teks ini bermaksud untuk menyajikan siswa argumen, mereka harus lebih memperhatikan struktur umum dan pola tata bahasa umum dari teks eksposisi analitis. Selain itu, teks ekspositori analitis lebih menantang atau sulit daripada jenis lainnya teks karena merupakan teks tipikal yang biasanya menggunakan kalimat yang lebih kompleks (Hanson \& Pandua dalam Nurjanah, 2018).

Kedua, teks eksposisi analitis sangat penting untuk diperhatikan diajarkan dan dikuasai oleh para siswa. Karena jaman modern seperti sekarang ini, semua orang memiliki hak dan kebebasan untuk mengungkapkan gagasan dan argumen keduanya di media cetak dan media elektronik. Karyuatry (2018) 
menyatakan hal itu pada kehidupan saat ini, jutaan produk tulisan tersebar luas di media elektronik untuk mengekspresikan dan berbagi ide dan argumen. Khususnya tentang isu atau topik terkini yang berkaitan dengan sosial, politik, budaya, agama, pendidikan, teknologi, kesehatan, dan lingkungan. Dengan mempelajari eksposisi analitis teks, siswa akan mendapatkan pengetahuan sebelumnya tentang bagaimana menulis sebuah argumen untuk meyakinkan dan membujuk pembaca.

Berdasarkan fakta di atas, guru harus lebih tanggap terhadap kondisi siswa. Guru sepenuhnya perlu mencari teknologi online sebagai alat bahasa yang canggih untuk membantu masalah siswa dalam menulis. Guru perlu mengetahui beberapa software komputer untuk membantu mereka dalam pengajaran dan proses pembelajaran, seperti Wiki, Facebook, Ms. Word, perangkat lunak Grammarly, dan lainnya (Kabilan, Ahmad, \& Abidin dikutip dalam Ghufron \& Rosyida, 2018). Penerapan teknologi komputer dalam pembelajaran bahasa digunakan untuk mencapai hasil yang diinginkan dalam pengembangan keterampilan menulis.

Grammarly adalah salah satu pemeriksa tata bahasa online yang populer saat ini. Grammarly didirikan oleh Maz Lytvyn dan Alex Shevchenko pada tahun 2009. Menurut Ghufron \& Rosyida (2018), Grammarly online proofreading situs web yang dapat digunakan untuk memindai dokumen untuk dikurangi kesalahan peneliti an dalam hal penggunaan kosakata, tata bahasa, dan mekanik. Secara otomatis mengidentifikasi kesalahan peneliti an, seperti kesalahan tata bahasa, pilihan kata, kesalahan ejaan, dan kesalahan tanda baca.

Grammarly tidak hanya memberikan kemampuan untuk mengidentifikasi tanda baca dan kata yang salah, tetapi juga kemampuan untuk mengidentifikasi fragmen dan menyajikan referensi tentang bentuk kata kerja (Daniels \& Leslie: 2013). Selain itu, Grammarly menawarkan banyak konten bagus untuk meningkatkan keterampilan menulis. Menggunakan Alat grammarly dapat meningkatkan motivasi, kepercayaan diri, dan keterlibatan dalam pembelajaran. Alat ini akan membangun kemandirian siswa tidak takut menulis meskipun mereka membuat kesalahan saat menulis. Karena itu, Para siswa hendaknya tidak segan-segan untuk menulis karena mereka mampu mengenali dan memperbaiki kesalahan peneliti an mereka dengan menggunakan alat Grammarly ini (Jayavalan \& Razali, 2018). Menggunakan Grammarly juga membantu siswa untuk mencapai tujuan akademis dan meningkatkan tulisan mereka dalam esai. Singkatnya, Grammarly adalah perangkat lunak internet otomatis yang menawarkan banyak fitur untuk meminimalkan kesalahan siswa dalam menulis menyajikan koreksi dan penjelasannya.

Berurusan dengan masalah siswa yang disebutkan di atas, peneliti dimaksudkan untuk menyelidiki perangkat lunak online efektif yang dapat digunakan meningkatkan keterampilan menulis siswa teks eksposisi analitik. Peneliti bermaksud untuk melaksanakan implementasi Grammarly tool yang dapat digunakan untuk memindai dokumen untuk kesalahan tata bahasa, kosakata, ejaan, dan tanda baca. Ia juga dapat memeriksa kesalahan tata bahasa dengan menyediakan penggunaan aturan tata bahasa yang benar. Perangkat lunak ini membantu siswa untuk memilih file kata yang tepat (pilihan kata) dan penggunaan kosa kata berdasarkan isinya. Saya juga memberikan saran, koreksi, serta penjelasan yang disajikan agar siswa dapat dengan mudah mengetahui dan memahami kesalahan yang mereka buat menulis melalui umpan balik otomatis. Penerapan otomatis umpan balik akan memberikan guru pada keterampilan menulis tingkat tinggi, sehingga berkembang antusiasme menulis siswa dan kualitas menulis (Wilson \& Czik, 2016).

\section{Metode Penelitian}

Dalam penelitian ini, peneliti menggunakan penelitian tindakan kelas untuk mendesain pelajaran ini. Penelitian tindakan kelas adalah jenis penelitian yang ditujukan untuk meningkatkan kualitas tindakan dalam konteks situasi sosial, melibatkankolaborasi dan kerjasama praktisi, peneliti, dan orang awam (Mulyasa, 2009). CAR bertujuan untuk mengetahui langkah inovatif dan efektif mengajar menulis di kelas. Penelitian tindakan kelas (PTK) adalah sebuah metode untuk mengetahui apa yang 
bekerja paling baik di kelas kita sendiri untuk mencari untuk solusi kelas dan meningkatkan pembelajaran siswa

Menurut Kemmis \& McTaggart yang dikutip dalam Anne Burns (2010: 189) menyatakan bahwa penelitian tindakan kelas dilakukan dalam beberapa langkah utama. Pertama, peneliti merencanakan strategi pengajaran untuk mengatasi masalah tersebut. Langkah selanjutnya adalah menerapkan strategi dan mengikuti dengan mengamati kegiatan belajar mengajar. Langkah terakhir adalah merefleksikan bagaimana strateginya meningkatkan atau mempengaruhi keterampilan menulis siswa.

Penelitian ini dilakukan di SMA Negeri 1 Jalaksana yang berlokasi di Jalan Raya Padamenak No. 62 Jalaksana Kab. Kuningan. Peneliti memilih sekolah ini karena peneliti adalah salah satu pengajar Bahasa Inggris di SMA Negeri 1 Jalaksana dan sudah mengetahui kondisi sekolah ini dan permasalahan yang ada dihadapi oleh siswa dalam menulis bahasa Inggris. Kelas XI MIPA 4 yang menjadi subjek penelitian merupakan salah satu kelas yang Peneliti ampu. Jumlah siswa di kelas ini berjumlah 35 (Tiga Puluh Lima) siswa yang terdiri dari 10 laki-laki dan 25 perempuan di tahun pelajarab 2019/2020.

Menurut Arikunto (2006), Instrumen Penelitian adalah alat bantú yang dipilih dan digunakan oleh peneliti dalam kegiatan mengumpulkan agar kegiatan tersebut menjadi sistematis. Instrumen pembelajaran dibuat untuk menunjang dalam kegiatan pembelajaran yang mencakup Silabus, RPP pada Siklus I dan II yang telah disusun sesuai dengan penggunaan Grammarly tool, dan dilengkapi dengan Lembar Kerja Siswa (LKS) pada Siklus I dan II. Instrumen pengumpulan data yang digunakan peneliti untuk mengumpulkan data antara lain menggunakan dua tekhik pengumpulan data yakni teknik tes dan teknis non tes. Teknik tes dengan memberikan post-test I dan post-test II pada setiap akhir siklus. Teknik non-tes yang digunakan adalah teknik observasi, kuisioner, dan wawancara. Observasi digunakan untuk mengetahui proses perkembangan motivasi belajar siswa secara klasikal dari hasil pengamatan observer, wawancara untuk mengetahui bagaimana perkembangan motivasi belajar siswa secara kualitatif dan tanggapan siswa terhadap metode yang digunakan dan kuisioner untuk mengetahui penilaian siswa terhadap tingkat motivasi mereka pada setiap siklus.

\section{Hasil dan Pembahasan}

Hasil penelitian ini dianalisis untuk melihat perbandingan keberhasilan penelitian dalam kegiatan siklus I dan siklus II dari hasil belajar siswa dari siklus I dan siklus II. Berdasarkan hasil penelitian yang telah dilaksanakan pada siswa kelas XI MIPA 4 SMA Negeri 1 Jalaksana melalui penerapan Grammarly tool pada materi teks analisis ekpositoris terbukti meningkatkan hasil belajar siswa.

\section{Pre Test}

Setelah memberikan pre-test kepada siswa, Peneliti menganalisis dan menghitung nilai pre-test menulis teks eksposisi analitik. Skor akan didasarkan pada lima aspek Penelitian: konten (C), organisasi $(\mathrm{O})$, Vocabulary/kosakata $(\mathrm{V})$, grammar/tata bahasa $(\mathrm{G})$, dan mekanik (M). Hasil pre-test ditunjukkan pada table 1 sebagai berikut:

Tabel 1 Hasil Pre Test Siswa

\begin{tabular}{cc}
\hline Aspek & Pencapaian Hasil Belajar \\
\hline Nilai Tertinggi & 75,00 \\
Nilai Terendah & 57,00 \\
$\sum$ Siswa Tuntas $\geq$ & 6 \\
$\sum$ Siswa Tidak Tuntas $\leq 74$ & 29 \\
Rata-rata & 66,43 \\
$\%$ Ketuntasan Klasikal & $16,67 \%$ \\
\hline
\end{tabular}


Berdasarkan data hasil tes awal diperoleh nilai tertinggi siswa yaitu 75,00 dan nilai terendah 57,00. Siswa dengan nilai tuntas berjumlah 6 siswa dan 29 siswa tidak tuntas. Nilai rata-rata siswa adalah 66,43 dengan presentase ketuntasan secara klasikal pada pre test ini adalah 16,67\%. Presentase tiap aspek dapat dikategorikan menggunakan kriteria yang dapat dilihat pada tabel 2 berikut.

Tabel 2 Presentase Aspek Tes Menulis Teks Analitik Ekspositori

\begin{tabular}{ccccc}
\hline No & Aspek & Presentase & Kategori & Level \\
\hline 1 & Conten & $75 \%$ & Baik & Di atas rata-rata \\
2 & Organization & $71 \%$ & Cukup & Perlu Peningkatan \\
3 & Vocabulary & $68 \%$ & Cukup & Perlu Peningkatan \\
4 & Grammar & $53 \%$ & Kurang & Di bawah rata-rata \\
5 & Mechanic & $54 \%$ & Kurang & Di bawah rata-rata \\
\hline
\end{tabular}

Dari tabel di atas dapat dilihat bahwa persentase terendah dari nilai siswa adalah grammar dan mechanic yang dikategorikan kurang (dibawah rata-rata). Tabel tersebut mengimplikasikan bahwa siswa kelas XI MIPA 1 SMA Negeri 1 Jalaksana mengalami kesulitan dalam menulis teks eksposisi analitik pada aspek Grammar/kebahasaan (tata bahasa) dan Mechanic (tanda baca dan ejaan). Persentase masing-masing kriteria adalah konten (75\%) yang mana kategori baik, organization (71\%) dalam kategori cukup, vocabulary (kosakata) (68\%) yang dikategorikan cukup, grammar (tata Bahasa) (53\%) yang dikategorikan kurang (di bawah rata-rata), dan mekanik (54\%) yang dikategorikan kurang.

Berdasarkan hasil pre-test, nilai rata-rata dari pre-test adalah 66,43. Kemudian, hanya ada enam siswa atau 16,67\% siswa yang mencapai Kriteria Ketuntasan Minimal (KKM) sedangkan 29 siswa lainya belum mencapai Kriteria Ketuntasa Minimal (KKM). Dari analisa data diatas dapat dibuktikan bahwa kemampuan menulis siswa kelas XI MIPA 4 SMAN 1 Jalaksana masih sangat rendah.

\section{Siklus I}

Hasil belajar siswa dalam penelitian ini adalah mengukur dan mengevaluasi kemampuan siswa dalam menulis teks eksposisi analitik yang telah dipelajari. Dalam post-test pertama ini, para siswa ditugaskan untuk menulis teks analitik yang terdiri dari thesis, dua argumen, dan reiteration/pengulangan. Temanya adalah tentang (a) bringing cell phone to school (membawa HP ke sekolah), (b) to use of social media (penggunaan media social), dan (c) the importance of washig hand (pentingnya mencuci tangan). Siswa menulis teks seperti biasa tanpa menggunakan alat Grammarly. Guru memeriksa hasil penulisan siswa menggunakan Grammarly. Kemudian, skor akan didasarkan pada lima aspek penulisan: conten/konten $(\mathrm{C})$, organizasion $(\mathrm{O})$, vocabulary/kosakata $(\mathrm{V})$, grammar/tata bahasa $(\mathrm{G})$, dan mechanic/sistematika(M). Berikut disajikan tabel 3 hasil evaluasi hasil belajar siklus I.

Tabel 3 Hasil Siklus I Siswa

\begin{tabular}{cc}
\hline Aspek & Pencapaian Hasil Belajar \\
\hline Nilai Tertinggi & 84,00 \\
Nilai Terendah & 62,00 \\
$\sum$ Siswa Tuntas $\geq$ & 15 \\
$\sum$ Siswa Tidak Tuntas $\leq 74$ & 21 \\
Rata-rata & 72,00 \\
$\%$ Ketuntasan Klasikal & $42,86 \%$
\end{tabular}

Berdasarkan data hasil tes siklus I diperoleh nilai tertinggi siswa yaitu 84,00 dan nilai terendah 62,00. Siswa dengan nilai tuntas berjumlah 15 siswa dan 21 siswa tidak tuntas. Nilai rata-rata siswa adalah 72,00 dengan presentase ketuntasan secara klasikal pada siklus I ini adalah 42,86\%. Berikut disajikan table perbandingan hasil tes awal dan siklus I. 
Tabel 4 Analisis Hasil Belajar Kognitif Setiap Siklus

\begin{tabular}{ccc}
\hline Komponen & Pre Test & Siklus I \\
\hline Rata-rata & 66,43 & 72,00 \\
Ketuntasan & $16,67 \%$ & $42,86 \%$ \\
\hline
\end{tabular}

Pencapaian ketuntasan siswa secara klasikal menunjukan adanya peningkatan dari pre test ke siklus I. Nilai rata-rata kelas pada pre test sebesar 66,43 meningkat pada siklus I menjadi 72,00. Ketuntasan klasikal hasil belajar pada siklus I sebesar 42,86\% akan tetapi hasil belajar pada siklus I belum memenuhi target sehingga harus dilaksanakan pemelajaran pada siklus II.

\section{Siklus II}

Dalam tahap ini, penulis memulai pembelajaran yang siklus kedua dengan melaksanakan proses belajar mengajar berdasarkan RPP yang telah dirancang. Setelah proses belajar-mengajar siklus kedua selesai, penulis mengadakan post-test 2 tentang keterampilan menulis teks eksposisi analitik yang telah dipelajari. Tujuan dari melakukan post-test kedua untuk mengetahui dan mengevaluasi pengembangan keterampilan siswa dalam menulis teks eksposisi analitik. Post-test kedua bertujuan untuk mengamati peningkatan kemampuan menulis siswa dari siklus pertama ke siklus kedua. Ini juga menentukan apakah penerapan alat Grammarly berhasil atau tidak. Berikut disajikan tabel 5 hasil evaluasi hasil belajar siklus II.

Tabel 5 Hasil Siklus II Siswa

\begin{tabular}{cc}
\hline Aspek & Pencapaian Hasil Belajar \\
\hline Nilai Tertinggi & 94,00 \\
Nilai Terendah & 70,00 \\
$\sum$ Siswa Tuntas $\geq$ & 32 \\
$\sum$ Siswa Tidak Tuntas $\leq 74$ & 4 \\
Rata-rata & 80,74 \\
$\%$ Ketuntasan Klasikal & $88,57 \%$ \\
\hline
\end{tabular}

Berdasarkan data hasil tes siklus II diperoleh nilai tertinggi siswa yaitu 94,00 dan nilai terendah 70,00. Siswa dengan nilai tuntas berjumlah 32 siswa dan 4 siswa tidak tuntas. Nilai rata-rata siswa adalah 80,74 dengan presentase ketuntasan secara klasikal pada siklus II ini adalah 88,57\%. Berikut disajikan table perbandingan hasil tes awal, siklus I dan siklus II.

Tabel 6 Analisis Hasil Belajar Kognitif Setiap Siklus

\begin{tabular}{cccc}
\hline Komponen & Pre Test & Siklus I & Silus II \\
\hline Rata-rata & 66,43 & 72,00 & 80,74 \\
$\%$ Ketuntasan & $16,67 \%$ & $42,86 \%$ & $88,57 \%$ \\
\hline
\end{tabular}

Dari diagram di atas, terlihat bahwa rata-rata nilai tes menulis siswa sebelum menggunakan alat Grammarly adalah 66,43. Sedangkan persentase kelas yang lulus Kriteria Ketuntasan Minimum adalah $20 \%$. Pada pre test, hanya empat siswa yang memenuhi kriteria sedangkan sisanya di luar target. Dapat disimpulkan bahwa nilai siswa dalam menulis gagal. Selanjutnya nilai rata-rata post-test 1 setelah digunakan Alat Grammarly pada siklus 1 adalah 72,00. Terlihat bahwa skor pada post test 1 lebih baik dari pada skor sebelumnya. Sedangkan persentase yang lulus Kriteria Ketuntasan Minimum adalah 42,86\%. Pada siklus I ini ada beberapa siswa yang lulus KKM. Namun, harus banyak perbaikan dan masih diperlukan karena skor post-test 1 tidak dapat mencapai kriteria target keberhasilan penelitian tindakan kelas dan perlu perbaikan pada siklus berikutnya sampai target tercapai dengan baik. Kemudian nilai rata-rata post test 2 siklus kedua adalah 80,74 dan persentase ketuntasan kelas yang lulus Kriteria Ketuntasan Minimum adalah 88,57\%. Terlihat ada peningkatan skor yang signifikan dari pre test ke siklus I begitupun dari siklus I ke siklus II. 
Indikator keberhasilan dalam penelitian ini adalah siswa mencapai nilai KKM $\geq 75$ sebanyak 75\% artinya hasil dalam Penelitian Tindakan Kelas (PTK) ini telah berhasil dan sudah mencapai target. Berdasarkan hasil penelitian secara keseluruhan menunjukan adanya peningkatan hasil belajar siswa dalam pelajaran Bahasa Inggris khususnya pada materi menulis teks analitik ekspositoris. Hasil ini menunjukan bahwa penerapan pembelajaran dengan penggunaan Grammarly tool merupakan salah satu cara yang tepat dalam penyampaian materi tersebut.

\section{Kesimpulan}

Penerapan Grammarly tool efektif dalam meningkatkan keterampilan menulis siswa kelas XI MIPA 4 SMA Negeri 1 Jalaksana. Hasil penelitian menunjukkan bahwa terdapat pengaruh yang signifikan dalam peningkatan nilai menulis siswa sebelum dan sesudah penerapan Grammarly tool. Terbukti dari peningkatan jumlah skor rata-rata menulis siswa dari pre-test adalah 66,43 atau 16,67\% yang lulus KKM, dan post-test1 adalah 72,00 atau 42,86\% yang lulus KKM siklus I, dan post test 2 adalah 80,74 atau $88,57 \%$ yang lulus KKM siklus II. Lebih jauh, peningkatan tidak hanya terjadi pada keterampilan menulis tetapi juga pada sikap siswa terhadap pembelajaran menulis, khususnya motivasi dan semangat mereka untuk belajar menulis. Dari penjelasan hasil tersebut, penulis menyimpulkan bahwa Grammarly tool adalah salah satu jenis alat bantu yang efektif membantu siswa dalam mengurangi kesalahan penulisan. Penerapan Grammarly tool berhasil meningkatkan keterampilan menulis siswa kelas XI IPA 4 SMA Negeri 1 Jalaksana.

\section{Daftar Pustaka}

Ariyanti. (2016). The Teaching of EFL Writing in Indonesia. Dinamika Ilmu, 16(2), 264.

Daniel , P., \& Leslie, D. (2013). Grammar Software Ready for EFL Writers?. OnCUE Journal, 9(4), 393.

Elita, Y. (2017). Teaching Reading Analytical Exposition Text by Using Questioning the Author (QtA) Strategy to the Eleventh Grade Students of SMA N 11 Palembang. [SKRIPSI] (Doctoral dissertation, UIN Raden Fatah Palembang)

Gilakjani, P. (2017). A Review of the Literature on the Integration of Technology into the Learning and Teaching of English Language Skills. International Journal of English Linguistics, 7(5), 95.

Ghufron, M. A., \& Rosyida, F. (2018). The Role ofGrammarly in Assessing English as a Foreign Language (EFL) Writing. Lingua Cultura, 12(4), 395-396. doi:10.21512/lc.v12i4.4582

Husin, M. S., \& Nurbayani, E. (2017). The Ability of Indonesian EFL Learners in Writig Academic Papers. Dinamika Ilmu, 17(2), 239-239.

Jayavalan, K., \& Razali, A. B. (2018). Effectiveness of Online Grammar Checker to Improve Secondary Students' English Narrative Essay Writing. International Research Journal of Education and Sciences (IRJES), 2(1), 2.

Karyuatry, Rizqan, \& Darayani. (2018). Grammarly As a Tool to Improve Studets' Writing Quality (Free Online Proofreader across the Boundaries). Jurnal SAINS dan HUMANIORA, 2(1).

Nurjanah, M. A. (2018). The Difficulties of Senior High School Students in Writing Analytical Expoition Texts. Journal of English Education and Linguistics, 1(2), 23

Parra G, L., \& Calero S, X. (2019). Automated Writing Evaluation Tools in the Improvement of Writing Skill. International Journal of Instruction, 12(2), 210- 211.

Paurillo, P. M. (2019). Research Writing Ability of Senior High School Students as Perceivedby Teachers of Sampled Schools in Quenzon City. International Journl of Social Sciences, 4(3), 1789.

Purwanto, M.N. (1996). Psikologi Pendidikan. Bandung: P.T.Remaja Rosdakarya.

Suharsimi, A. (2006). Prosedur Penelitian Suatu Pendekatan Praktek. Jakarta: Rineka Cipta. 
Tiryaki, E. N. (2016). Identification Types and Discourse Markers in Turkish Language Teacher Candidates' Argumentative Texts. Journal of Education and Training Studies, 5(2), 63. doi:10.11114/jets.v5i2.2033

Wilson, J., \& Czik, A. (2016). Automated Essay Evaluation Software in English Language Arts Classroom: Effects on Teacher Feedback, Student Motivation, and Writing Quality. Computers \& Education, 100, 94-109. 